\title{
GASTRIC PROTEOLYSIS IN DISEASE \\ 2. THE PROTEOLYTIC ACTIVITY OF GASTRIC JUICE AND GASTRIC MUCOSAL EXTRACTS FROM PATIENTS WITH CHRONIC GASTRIC AND DUODENAL ULCER
}

\author{
BY \\ W. H. TAYLOR \\ Department of Clinical Biochemistry, Radcliffe Infirmary, University of Oxford
}

(RECEIVED FOR PUBlication JANUARY 30, 1959)

The secretion of pepsin in the gastric juice of patients with peptic ulcer has been the subject of much investigation. Early work was carried out mainly on resting juices or on the aspirated products of an Ewald meal (Willcox, 1908 ; Boas, 1925 ; Hirsch-Mamroth and Rindfleisch, 1925; Polland and Bloomfield, 1930; Vanzant, Osterberg, Alvarez, and Rivers, 1933 ; Mullins and Flood, 1935), and appeared to establish that in both gastric and duodenal ulcer, but more strikingly so in the latter, the pepsin concentration of the gastric juice is increased. The total output of pepsin in response to a given stimulus is further increased because a greater volume of juice is secreted. Ihre (1938) found, however, in both chronic duodenal and gastric ulcer that the pepsin concentrations of the fasting and histamine secretions were normal and that only after insulin hypoglycaemia were they raised. Le Veen and Hallinger (1947) presented evidence that the absolute peptic activity of the fasting gastric juice in peptic ulcer was normal and only appeared raised because of the lower $p H$ at which the fasting juice is usually secreted in this disease. Chinn, Book, and Beams (1951) also were unable to find any significant difference in the pepsin concentration of nocturnal or insulin juices between patients with duodenal ulcer and normal controls. Janowitz and Hollander (1951, 1952) determined the total pepsin content of the basal gastric secretion (" in the absence of all intentional and avoidable stimuli ") over periods of one hour, and found that in duodenal ulcer the average basal output of pepsin is up to three times that of normal controls, whereas in gastric ulcer it is not significantly different from normal. Whilst, therefore, it is doubtful if the actual concentration of pepsin is increased, it seems established that, in duodenal ulcer at any rate, because of the increased volume of gastric secretion, the total output of pepsin by the mucous membrane both at rest and in response to a given stimulus is usually greater than in normal subjests.

The underlying assumption in these investigations has been that the gastric mucous membrane of patients with peptic ulcer secretes normal pepsin. Proteolytic activity has been determined only near $p \mathrm{H} 2$. The possibility that modified pepsin, or enzymes different from pepsin, may be present has not been considered. An investigation of this possibility is now described.

\section{Materials and Methods}

The materials and methods used have been described previously (Taylor, 1956, 1957, 1959a). Portions of stomach from patients undergoing partial gastrectomy were cooled immediately to below $5^{\circ} \mathrm{C}$. The mucous membrane was dissected away from the muscle coat, cut into small pieces, and extracted in a blender with $2 \%(\mathrm{w} / \mathrm{v})$ sodium chloride. The extract was then centrifuged to remove debris and stored at $-5^{\circ} \mathrm{C}$. The separation of fundic and pyloric mucosa has already been defined (Taylor, 1959c).

\section{Results}

Gastric Juice.-Three patients with duodenal ulcer and one with gastric ulcer exhibited $p \mathrm{H}$ activity curves with two maxima when their histamine-stimulated gastric juices digested plasma protein below $p H 5$ (Table I). The maxima occurred between $p H 1.9$ and 2.4, and 3.3 and 3.6 , and are thus similar to the two maxima which occurred with the gastric juice of 15 of 17 normal subjects under the same experimental conditions (Taylor, 1959a).

The remaining seven patients each exhibited a different $p \mathrm{H}$ activity curve for the digestion of plasma protein or plasma albumin fraction $\mathrm{V}$, in which three maxima occurred below $p H 5$. The $p \mathrm{H}$ ranges of these maxima were 1.5 to $2.1,2.5$ to 3.1 , and 3.3 to 3.8 (Table I). The $p \mathrm{H}$ activity curve for the digestion of egg albumen was 
TABLE I

pH MAXIMA FOR DIGESTION OF PROTEINS BELOW pH 5 BY HISTAMINE-STIMULATED GASTRIC JUICES OF PATIENTS WITH PEPTIC ULCER

\begin{tabular}{|c|c|c|c|c|c|c|c|}
\hline \multirow[b]{2}{*}{ Patient } & \multirow[b]{2}{*}{ Substrate } & \multicolumn{2}{|c|}{$p \mathrm{H} 1.5$ to 2.4} & \multicolumn{2}{|c|}{$p \mathrm{H} 2.5$ to 3.2} & \multicolumn{2}{|c|}{$p H 3.3$ to 4.0} \\
\hline & & $\underset{p \mathrm{H}}{\operatorname{Maximum}}$ & $\begin{array}{l}\text { Amino-acid N } \\
\text { Released (mg.) }\end{array}$ & $\underset{p \mathrm{H}}{\operatorname{Maximum}}$ & $\begin{array}{l}\text { Amino-acid N } \\
\text { Released (mg.) }\end{array}$ & $\underset{p H}{\operatorname{Maximum}}$ & $\begin{array}{c}\text { Amino-acid } \\
\text { Released (mg.) }\end{array}$ \\
\hline \multirow{3}{*}{$\begin{array}{r}1 \\
2 \\
3 \\
* 4 \\
5 \\
6 \\
7 \\
8 \\
* 9 \\
* 10 \\
11 \\
\\
5 \\
6 \\
8\end{array}$} & \multirow[t]{3}{*}{$\begin{array}{l}\text { Plasma protein } \\
\\
\begin{array}{l}\text { Bovine plasma albumin } \\
\text { fraction } \mathbf{V}\end{array} \\
\text { Egg albumen }\end{array}$} & \multirow{3}{*}{$\begin{array}{l}1.9 \\
2.2 \\
2.1 \\
2.4 \\
2.1 \\
1.8 \\
1.8 \\
1.5 \\
1.6 \\
1.9 \\
2.0 \\
1.5 \\
1.6 \\
1.6\end{array}$} & \multirow{3}{*}{$\begin{array}{l}0.60 \\
0.55 \\
0.62 \\
0.78 \\
0.46 \\
0.45 \\
0.46 \\
0.35 \\
0.66 \\
0.57 \\
\\
0.65 \\
0.31 \\
0.24 \\
0.31\end{array}$} & \multirow{3}{*}{$\begin{array}{l}\text { Z } \\
\bar{Z} \\
\overline{2 \cdot 7} \\
2 \cdot 9 \\
3 \cdot 0 \\
2 \cdot 5 \\
2 \cdot 6 \\
2 \cdot 6 \\
3 \cdot 1 \\
2 \cdot 6 \\
2 \cdot 8 \\
3 \cdot 1\end{array}$} & \multirow{3}{*}{$\begin{array}{l}- \\
= \\
\overline{-} \\
0.41 \\
0.35 \\
0.48 \\
0.40 \\
0.57 \\
0.64 \\
0.67 \\
0.22 \\
0.14 \\
0.17\end{array}$} & $\begin{array}{l}3.6 \\
3 \cdot 3 \\
3 \cdot 3 \\
3.3 \\
3.7 \\
3.7 \\
3.8 \\
3.3 \\
3.5 \\
3.4\end{array}$ & \multirow[t]{2}{*}{$\begin{array}{c}0.45 \\
0.50 \\
0.60 \\
0.83 \\
0.41 \\
0.36 \\
0.45 \\
0.38 \\
0.63 \\
0.64 \\
0.72 \\
\text { g activity }\end{array}$} \\
\hline & & & & & & \multirow{2}{*}{$\begin{array}{c}3 \cdot 8 \\
\text { Declin } \\
,,\end{array}$} & \\
\hline & & & & & & & ", \\
\hline
\end{tabular}

* Patients with gastric ulcer; remainder had duodenal ulcer.

In the tables and figures the amounts of amino-acid nitrogen released are those in the whole digest, which consisted of 3 to $5 \mathrm{ml}$. of buffer, 0.5 to $1 \mathrm{ml}$. of gastric juice or extract, and $1 \mathrm{ml}$. of plasma or of $5 \%(\mathrm{w} / \mathrm{v})$ albumin solution. Temperature $37^{\circ}$, time $3 \mathrm{hr}$.

TABLE II

pH MAXIMA FOR DIGESTION OF PROTEINS BELOW $p$ H 5 BY GASTRIC MUCOSAL EXTRACTS OF PATIENTS WITH PEPTIC ULCER

\begin{tabular}{|c|c|c|c|c|c|c|c|c|}
\hline \multirow[b]{2}{*}{ Patient } & \multirow[b]{2}{*}{ Extract } & \multirow[b]{2}{*}{ Substrate } & \multicolumn{2}{|c|}{ pH 1.5 to 2.4} & \multicolumn{2}{|c|}{$p H 2.5$ to 3.2} & \multicolumn{2}{|c|}{$p \mathrm{H} 3.3$ to 4.0} \\
\hline & & & $\underset{p \mathrm{H}}{\operatorname{Maximum}}$ & $\begin{array}{l}\text { Amino-acid } \\
\text { N Released } \\
\text { (mg.) }\end{array}$ & $\underset{p \mathrm{H}}{\operatorname{Maximum}}$ & $\begin{array}{l}\text { Amino-acid } \\
\text { N Released } \\
\text { (mg.) }\end{array}$ & $\underset{p H}{\operatorname{Maximum}}$ & $\begin{array}{l}\text { Amino-acid } \\
\text { N Released } \\
\text { (mg.) }\end{array}$ \\
\hline$* 9$ & \multirow[t]{2}{*}{ Whole mucosal } & Plasma protein & 1.8 & 0.65 & $2 \cdot 6$ & 0.63 & $3 \cdot 5$ & 0.69 \\
\hline $\begin{array}{l}12 \\
13\end{array}$ & & Human serum albumin & $\begin{array}{l}1 \cdot 5 \\
2 \cdot 4\end{array}$ & $\begin{array}{l}0.63 \\
0.63\end{array}$ & $2 \cdot 6$ & $\begin{array}{c}0.69 \\
-\end{array}$ & $\begin{array}{l}3 \cdot 7 \\
3 \cdot 6\end{array}$ & $\begin{array}{l}0.74 \\
0.73\end{array}$ \\
\hline $\begin{array}{r}8 \\
* 10 \\
11 \\
14 \\
15 \\
16 \\
17 \\
18 \\
19\end{array}$ & \multirow[t]{5}{*}{ Fundic } & Plasma protein & $\begin{array}{l}2.2 \\
1.7 \\
2.2 \\
2.1 \\
2.0 \\
1.6 \\
2.1 \\
1.9 \\
1.8\end{array}$ & $\begin{array}{l}0.70 \\
0.34 \\
0.90 \\
0.61 \\
0.64 \\
0.63 \\
0.70 \\
0.77 \\
0.63\end{array}$ & $\begin{array}{l}2.9 \\
2.7 \\
2.9 \\
3.0 \\
3.0 \\
2.5 \\
3.1 \\
3.2 \\
-\end{array}$ & $\begin{array}{c}0.77 \\
0.36 \\
0.90 \\
0.68 \\
0.63 \\
0.61 \\
0.82 \\
0.85 \\
-\end{array}$ & $\begin{array}{l}3.5 \\
3.6 \\
3.6 \\
3.9 \\
3.9 \\
3 \cdot 3 \\
3.9 \\
3.9 \\
3 \cdot 5\end{array}$ & $\begin{array}{l}0.63 \\
0.24 \\
0.85 \\
0.70 \\
0.46 \\
0.55 \\
0.64 \\
0.82 \\
0.72\end{array}$ \\
\hline 8 & & Human serum albumin & $2 \cdot 3$ & 0.76 & - & - & $3 \cdot 6$ & 0.87 \\
\hline $\begin{array}{l}20 \\
21 \\
22 \\
23\end{array}$ & & $\begin{array}{l}\text { Bovine plasma albumin } \\
\text { fraction } V\end{array}$ & $\begin{array}{r}2 \cdot 1 \\
1.5 \\
\end{array}$ & $\begin{array}{r}0.30 \\
0.63 \\
\text { au }\end{array}$ & $\begin{array}{ll}2 \cdot 9 & \\
2 \cdot 5 & \\
& \text { Pla }\end{array}$ & $\begin{array}{r}0.27 \\
0.63 \\
\text { au }\end{array}$ & $\begin{array}{l}3 \cdot 8 \\
3 \cdot 4 \\
3 \cdot 6 \\
3 \cdot 5\end{array}$ & $\begin{array}{l}0.25 \\
0.84 \\
0.80 \\
0.91\end{array}$ \\
\hline 8 & & \multirow[t]{2}{*}{ Egg albumen } & $1 \cdot 5$ & $0 \cdot 30$ & $2 \cdot 5$ & 0.22 & \multicolumn{2}{|c|}{ Declining activity } \\
\hline 11 & & & & 0.41 & & $0 \cdot 20$ & ," & , \\
\hline $\begin{array}{l}17 \\
18\end{array}$ & Lesser curve & Plasma protein & $\begin{array}{l}1.9 \\
1.9\end{array}$ & $\begin{array}{l}0 \cdot 62 \\
0 \cdot 18\end{array}$ & $\overline{3 \cdot 1}$ & $\overline{0 \cdot 20}$ & $\begin{array}{l}3 \cdot 6 \\
3 \cdot 9\end{array}$ & $\begin{array}{l}0.50 \\
0.20\end{array}$ \\
\hline $\begin{array}{r}8 \\
* 10 \\
14 \\
15 \\
16 \\
17 \\
18 \\
24 \\
25\end{array}$ & \multirow[t]{3}{*}{ Pyloric } & Plasma protein & $\begin{array}{l}1 \cdot 9 \\
2 \cdot 1 \\
1 \cdot 7 \\
1 \cdot 7 \\
2 \cdot 1 \\
1 \cdot 8 \\
1 \cdot 7 \\
2 \cdot 1\end{array}$ & $\begin{array}{l}0.30 \\
0.17 \\
0.56 \\
0 \cdot 16 \\
0 \cdot 20 \\
0.12 \\
0 \cdot 25 \\
0.70\end{array}$ & $\begin{array}{l}2 \cdot 5 \\
2 \cdot 8 \\
2 \cdot 5 \\
2 \cdot 8 \\
3 \cdot 1 \\
2 \cdot 8 \\
3 \cdot 0\end{array}$ & $\begin{array}{l}0.49 \\
0.22 \\
0.55 \\
0.25 \\
0.13 \\
0.18 \\
0.20\end{array}$ & \multicolumn{2}{|c|}{\begin{tabular}{c|r}
3.7 & 0.47 \\
Declining activity \\
3.4 & 0.50 \\
Declining activity \\
3.4 & 0.28 \\
Declining activity \\
3.8 & 0.28 \\
Declining activity
\end{tabular}} \\
\hline 25 & & & 2.0 & 0.20 & $3 \cdot 2$ & 0.25 & , & , \\
\hline $\begin{array}{r}8 \\
11\end{array}$ & & Egg albumen & $\begin{array}{cc}1.5 \\
1.4 \\
\text { and } 2 \cdot 2\end{array}$ & $\begin{array}{l}0.15 \\
0.09 \\
0.08\end{array}$ & $\begin{array}{l}3 \cdot 0 \\
\text { Declinin }\end{array}$ & $\begin{array}{r}0 \cdot 12 \\
\text { activity }\end{array}$ & $\begin{array}{c}\text { Declinin } \\
, "\end{array}$ & activity \\
\hline
\end{tabular}

* Patients with gastric ulcer; the remainder had duodenal uker. 
determined in three of these patients, but only two maxima, at $p H s 1.5$ to 1.6 and 2.6 to 3.1 , were observed. The gastric juice of one patient (No. 11) failed to digest clupeine sulphate.

Whole Gastric Mucosal Extracts. - Whole gastric mucosal extracts from one patient with gastric ulcer and two with duodenal ulcer have been incubated with plasma protein or human serum abumin. One patient showed a normal $p \mathrm{H}$ activity curve with two maxima, but two gave curves with three maxima (Table II).

Fundic Mucosal Extracts. - Fundic mucosal extracts from nine patients with duodenal ulcer and one with gastric ulcer digested plasma protein or plasma albumin fraction $\mathrm{V}$ with three maxima below $p H 5$ (Fig. 1, Table II). The three maxima occurred within the ranges, $p \mathrm{H} 1.6$ to $2.2,2.5$ to 3.2 , and 3.3 to 3.9. One patient (No. 19) exhibited a normal $p \mathrm{H}$ activity curve with only two maxima, and two (Nos. 22 and 23) exhibited abnormal curves with a single maximum at $p \mathrm{H} 3.5$ to 3.6. These latter curves were, however, not symmetrical ; there was high activity at $p \mathrm{H} 2$, but no significant maxima could be distinguished.

Of those patients showing three maxima, the highest proteolytic activity occurred in four at the middle maximum, and in a fifth patient the lowest and middle maxima exhibited equal proteolytic activity. In two patients a strip of mucosa 1 in. wide, taken from the length of the lesser curve of the stomach but excluding the 2 in. nearest to the pyloro-duodenal junction, was extracted separately. One such extract digested plasma protein with three maxima below $p H 5$, but the other showed only two maxima. One extract (No. 8) which digested plasma with three maxima digested

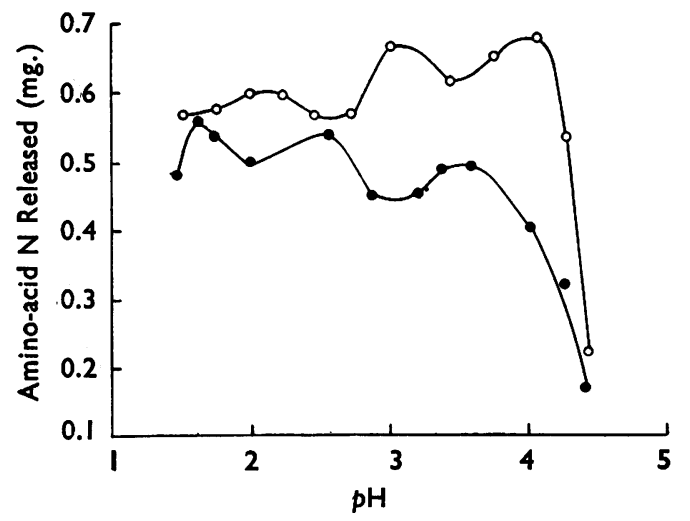

FIG. 1.-The $p H$ activity curves for the digestion of plasma protein by fundic (O) and pyloric (O) mucosal extracts from a patient with duodenal ulcer, $37^{\circ} \mathrm{C} ., 3 \mathrm{hr}$. serum albumin with two. The experimental readings showed a third maximum, but this was not significant by the criteria that are applied (Taylor, 1956, 1959a). Two extracts which digested plasma with three maxima digested egg albumen with only two.

Pyloric Mucosal Extracts. - Pyloric mucosal extracts from eight patients with duodenal ulcer and one with gastric ulcer have been incubated with plasma protein (Table II). Of these extracts three gave $p \mathbf{H}$ activity curves with three maxima at $p \mathrm{H} 1.7$ to $1.9,2.5$ to 2.8 , and 3.4 to 3.8 (Fig. 1). Six gave curves with two maxima occurring in the $p H$ ranges 1.7 to 2.1 and 2.8 to 3.4. Two extracts, one of which had digested plasma protein with three maxima, digested egg albumen with two maxima at $p \mathrm{H} 1.4$ to 1.5 and 2.2 to 3.0.

Proteolytic Activity at $p H 5$ to 8.-Proteolytic activity between $p \mathrm{H} 5$ and 8 has been investigated in seven patients with duodenal ulcer. The whole mucosal extract of one was inactive when incubated with plasma, but that of a second patient digested human serum albumin weakly with a maximum at $p \mathbf{H}$ 7.2. Four fundic extracts were incubated with plasma; two were inactive, one was active over the range $p H 6.4$ to 7.4 , but no maximum could be detected, and the fourth was weakly active with a maximum at $p \mathrm{H}$ 7.2. The pyloric extracts of two of these patients digested plasma protein weakly at $p H 6.4$ to 7.4 , but no maxima could be distinguished. The pyloric extract of a seventh patient was unable to hydrolyse crystalline bovine plasma albumin. Thus proteolytic activity was present in three of six extracts which contained fundic mucosa, and in three of five containing pyloric mucosa.

Hydrolysis of Benzyloxycarbonyl-L-glutamyl-L tyrosine.-This compound is a specific substrate for pepsin and is hydrolysed with a $\mathrm{pH}$ maximum near 4.0 (Fruton and Bergmann, 1939). Normal gastric juice, although digesting most proteins with two maxima below $p H$ 5, digests this substrate with only one maximum at $p H 4.0$ (Taylor, 1959a). Histamine gastric juice from two patients with peptic ulcer and a fundic mucosal extract from a third have been incubated with the substrate for 21 hours. Although the juices and extract each digested plasma protein with three maxima below $p H 5$, they hydrolysed the peptide with only one maximum at $p \mathrm{H} 3.6$ to 4.0 (Fig. 2), and thus did not differ from normal gastric juice. This result indicates that a similar active site on pepsin is present in normal subjects and in patients with peptic ulcer, but offers no explanation of the origin of the third maximum. 


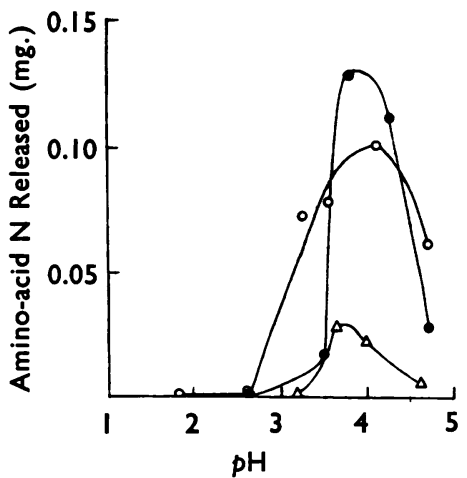

FiG. 2.-The $p \mathrm{H}$ activity curves for hydrolysis of benzyloxycarbonylL-glutamyl-L-tyrosine by gastric juice from a patient with gastric ulcer $(\Delta)$, a patient with duodenal ulcer $(\bullet)$, and by a fundic mucosal extract from a patient with duodenal ulcer $(0), 37^{\circ} \mathrm{C}$., $3 \mathrm{hr}$.

Salt Fractionation of Gastric Juice.-In an attempt to separate enzymes responsible for the three proteolytic $p H$ maxima that have been observed, gastric juice from patients with peptic ulcer has been subjected to fractionation with ammonium sulphate, sodium chloride, and magnesium sulphate. As was the case with normal gastric juice (Taylor, 1959a), consistent results were difficult to achieve and, as fractionation proceeded, activity was lost. The distinction between maxima and minima was thus blurred, leading to curves with a plateau. It seemed that no separation of one or other peak was taking place, and it was certainly never possible to achieve concentration of the middle peak alone.

\section{Discussion}

The most obvious difference between the proteolytic $p \mathrm{H}$ activity curves of patients with gastric or duodenal ulcer and those of normal subjects is the presence of three maxima in many of the former and the only occasional presence of three maxima in the latter. In peptic ulcer, three maxima were found for the proteolysis of plasma protein in six of 10 samples of histamine juice, in all but one of the fundic extracts, and in three of the nine pyloric extracts examined. This contrasts with normal gastric juice, which exhibited three maxima only in two of 17 subjects (Taylor, 1959a), and with the fundic extracts of five normal subjects and the pyloric extracts of four, all of which digested plasma protein with only two $p H$ maxima (Taylor, 1959c).

This difference of gastric proteolytic pattern may be demonstrated in another way. Seventeen normal gastric juices acting on plasma protein exhibited a fall of activity, measured from whichever of the maxima at $p H 1.7$ to 2.4 and 3.3 to 4.0 was the less active to the minimum point in the $p \mathrm{H}$ range 2.5 to 3.2 , of $5 \%$ to $34 \%$, with a mean of $13 \%$. In 10 patients with peptic ulcer the fall varied from $3 \%$ to $16 \%$ (mean $7.7 \%$ ) and was significantly lower $(t=2.068, P<0.05)$. There is thus in peptic ulcer a filling-in of the minimum between the two normal maxima, which in about two-thirds of the patients takes the form of a third maximum. In about one-third of the patients this maximum at $p \mathrm{H} 2.5$ to 3.1 becomes the most active point of the whole $p \mathrm{H}$ activity curve.

The curves for egg albumen require special comment. Five of seven normal subjects, whose gastric juice digested other substrates with two maxima, digested egg albumen with only one maximum at $p \mathrm{H} 1.5$ to 1.8 (Taylor, 1959a). The two remaining subjects, who had shown three maxima for the digestion of other substrates, digested egg albumen with two maxima, the second occurring at $p \mathrm{H} 2.5$ to 2.8 . In patients with peptic ulcer, however, all the histamine juices, fundic extracts, and pyloric extracts that have been examined digest egg albumen with two maxima and other substrates with three. One possible explanation of these results might therefore be that there is in the normal population a group of subjects whose gastric juice digests most substrates with three maxima but egg albumen with two, and that peptic ulceration occurs more frequently in this group than in the remainder of the population.

The proteolytic activity of fundic and pyloric extracts from the same patient can be directly compared. In five of seven patients the $p H$ maximum in the range 1.6 to 2.4 occurred at higher $p \mathrm{H}$ values in fundic extracts than in pyloric extracts. The reverse was, however, true in the two remaining cases. The three pyloric extracts with triple-peaked $p \mathrm{H}$ activity curves also showed $p \mathrm{H}$ maxima which were generally at lower $p \mathrm{H}$ values than the corresponding maxima of the fundic extracts. A similar tendency for pyloric extracts to exert maxima at lower $p H$ values than fundic extracts has been described in normal subjects (Taylor, 1959c).

The observations upon proteolytic activity at pH 5 to 8 in patients with peptic ulcer resembled those of normal subjects in that some patients showed weak activity but others showed none, and that occasional maxima occurred at $p H$ 7.2. The chief, and anticipated, difference from normal subjects was the absence of the second peak at 
pH 7.6 to 7.9 which is thought to arise from salivary contamination (Taylor, 1959d).

Three hypotheses may be advanced to explain the occurrence of $p \mathrm{H}$ activity curves with three maxima below $p \mathrm{H} 5$. First, there might be formation in the mucosa and secretion into the gastric juice of a differing proportion of normal fundic and pyloric pepsins (Taylor, 1959c). Since the former enzyme exhibits $p \mathrm{H}$ maxima at $p \mathrm{H} 1.8$ to 2.4 and 3.3 to 4.0 , and the latter at $p \mathrm{H} 1.5$ to 1.9 and 2.5 to 3.2 , a mixture of both could give rise to a curve with maxima in the required positions. The chief difficulty about this hypothesis is that in such a mixture the maximum at $p \mathrm{H} 1.8$ to 2.4 ought to be quantitatively higher than the others, but only in four patients was this so. It is also difficult on this hypothesis to explain the observations made upon egg albumen, for if normal gastric juice digests egg albumen with only a single maximum and yet contains a mixture of two types of pepsin, it would seem that other mixtures of the two enzymes should also yield only one maximum and not two. A further difficulty arises over those pyloric extracts which exhibit a new third maximum at $\mathrm{pH} 3.3$ to 3.9 . In these patients it must also be supposed that the pyloric mucosa contains more of the fundic type cells.

The second hypothesis is that, in addition to the normal pepsins, a new enzyme is formed and secreted which exerts maximal activity at $p \mathrm{H} 2.5$ to 3.2. Such an explanation would be compatible with the finding that activity over this $p \mathrm{H}$ range may exceed that at $p \mathrm{H} 1.6$ to 2.4 and 3.3 to 4.0 , and it would account for the observations on egg albumen. It would not account for the third maximum at $p \mathrm{H} 3.3$ to 4.0 which occurs in some of the pyloric extracts, unless the hypothesis were extended to include a new pyloric enzyme or the presence in the pylorus of fundic type cells. Attempts to isolate the postulated enzyme by salt fractionation have so far been unsuccessful.

The third hypothesis is that abnormal pepsins are formed and secreted in patients with peptic ulcer which will each digest proteins with three instead of two maxima below $p H 5$. One such enzyme might be produced by fundic cells and a second by pyloric cells. This third hypothesis is not at variance with any of the observations so far made. There is evidence that the double maximal pH activity curves which occur in normal subjects arise from the presence in the pepsin molecule of two active centres (Taylor, 1959b). If abnormal pepsins exhibiting three maxima do occur, the acquisition of a third type of active centre would seem a possible explanation of their action. The ability to synthesize the third site for an abnormal fundic pepsin already exists in normal pyloric mucous membrane and the third site for an abnormal pyloric pepsin in normal fundic mucous membrane.

The available evidence does not allow any final distinction to be made between the three hypotheses, but the first seems the least likely. If either the second or third hypothesis proves to be correct it would mean that in peptic ulcer an abnormal or pathological gastric proteinase is being elaborated and secreted. Evidence has already been presented that in pernicious anaemia such a phenomenon may occur (Taylor, 1959e).

\section{Summary}

The proteolytic $p \mathrm{H}$ activity curves of the gastric juice and/or gastric mucosal extracts of 22 patients with duodenal ulcer and three with gastric ulcer have been investigated. No differences of proteolytic activity were found between the two types of peptic ulcer.

In seven of 11 patients the histamine gastric juice digested proteins other than egg albumen with three maxima below $p H 5$. The maxima occurred at $p \mathrm{H} 1.5$ to $2.1,2.5$ to 3.1 , and 3.3 to 3.8. The remaining four patients exhibited normal $p \mathrm{H}$ activity curves with two maxima in the $p H$ ranges 1.6 to 2.4 and 3.3 to 4.0 .

The gastric juice of three patients digested egg albumen with two maxima, at $p H 1.5$ to 1.6 and 2.6 to 3.1 , in contrast to the single maximum for this substrate exhibited by normal subjects.

Whole and fundic mucosal extracts from 12 of 16 patients also digested proteins other than egg albumen below pH 5 with three maxima, which occurred at $p \mathrm{H} 1.5$ to $2.2,2.5$ to 3.2 , and 3.3 to 3.9. The fundic extracts of two patients digested egg albumen with two maxima at $p \mathrm{H} 1.5$ to 1.7 and 2.5 to 3.1 .

The pyloric mucosal extracts of three of nine patients digested proteins with three maxima at $p \mathrm{H} 1.7$ to $1.9,2.5$ to 2.8 , and 3.3 to 3.8 , but in the other six the normal pyloric pattern of two maxima, at $p H 1.7$ to 2.1 and 2.8 to 3.4 , was observed.

The gastric juice of two patients with peptic ulcer and the fundic mucosal extract of a third hydrolysed the specific pepsin substrate benzyloxycarbonyl-L-glutamyl-L-tyrosine with a single maximum at $p \mathrm{H} 3.6$ to 4.0 , resembling that exhibited by normal subjects.

Separation by salt fractionation of individual enzymes responsible for individual $p H$ maxima was not achieved. 
Proteinase activity was present over the $p H$ range 6.4 to 7.4 in three of six extracts containing fundic mucosa and in three of five containing pyloric mucosa. With two extracts a maximum at $p \mathrm{H} 7.2$ was observed.

Hypotheses that would account for $p \mathrm{H}$ activity curves with three maxima are discussed. The available evidence favours the formation and secretion by the mucous membrane of an abnormal enzyme or enzymes.

The differences between normal subjects and patients with peptic ulcer would be explained if peptic ulceration occurred more readily in the small group of normal subjects who digest proteins with three maxima than in the remainder of the population.

I wish to thank Miss Barbara Hunt and Mr. Brian Collett for skilful technical assistance, the surgeons of the Radcliffe Infirmary for access to patients and post-operative material, Dr. P. W. Kent for a gift of benzyloxycarbonyl-L-glutamyl-L-tyrosine, and Mr. J. R. P. O'Brien and Dr. R. B. Fisher for reading and criticizing the D.M. thesis from which the material of this paper is abridged.

\section{REFERENCES}

Boas, I. (1925). Dtsch. med. Wschr., 51, 511.

Chinn, A. B., Book, D. T., and Beams, A.J. (1951). Gastroenterology, $18,427$.

Fruton, J. S., and Bergmann, M. (1939). J. biol. Chem., 127, 627.

Hirsch-Mamroth, P., and Rindfleisch, H. (1925). Dtsch. med. Wschr. 51, 512 .

Ihre, B. (1938). Acta med. scand., Suppl. 95.

Janowitz, H.D., and Hollander, F. (1951). J. appl. Physiol., 4, 53.

- (1952). J. clin. Invest., 31, 338.

Le Veen, H. H., and Hallinger, L. (1947). Ibid., 26, 761.

Mullins, C. R., and Flood, C. A. (1935). Ibid., 14, 793

Polland, W. S., and Bloomfield, A. L. (1930). Tbid., 9, 107.

Taylor, W. H. (1956). D.M. Thesis, University of Oxford.

- (1957). Analyst, 82, 488.

- (1959a). Biochem. J., 71, 73

- (1959b). Ibid., 71, 373.

- (1959c). Ibid., 71, 384.

- (1959d). Ibid., 71, 626

(1959e). J. clin. Path., 12, 210

F. Alvarez, W. C., and Rivers, A. B. (1933). J. clin. Invest., 12, 557.

Willcox, W. H. (1908). Lancet, 2, 220. 